\title{
Correction to: An efficient hybrid model for thermal analysis of deep borehole heat exchangers
}

\author{
Yazhou Zhao ${ }^{1,2,3}$, Zhonghe Pang ${ }^{1,2,3^{*}}$, Yonghui Huang ${ }^{1,2,3}$ and Zhibo $\mathrm{Ma}^{4}$
}

\author{
The original article can be \\ found online at https://doi. \\ org/10.1186/s40517-020- \\ 00170-z
}

\section{*Correspondence:} z.pang@mail.iggcas.ac.cn 1 Key Laboratory of Shale Gas and Geoengineering, Institute of Geology and Geophysics, Chinese Academy of Sciences, 19, BeiTucheng West Road, Chaoyang District, Beijing 100029, China Full list of author information is available at the end of the article

\section{Correction to: Geotherm Energy (2020) 8:18 https://doi.org/10.1186/s40517-020-00170-z}

After publication of our article it was brought to our attention that we had omitted to include the credit line for Figure 1. The corrected Figure 1 caption with the credit line is given below:

"Schematic of heat transfer process for deep borehole heat exchanger: inverse loop (left) and forward loop (right). Reproduced with permission from Elsevier from Bär et al. Energy Procedia 76 (2015) 351-360; this work is licensed under the CC BY-NC-ND license (http://creativecommons.org/licenses/by-nc-nd/4.0/)."

There were a number of errors found in the references section. The corrected references are given in this Correction article.

We apologize to readers for these errors.

The original article has been corrected.

\section{Author details}

'Key Laboratory of Shale Gas and Geoengineering, Institute of Geology and Geophysics, Chinese Academy of Sciences, 19, BeiTucheng West Road, Chaoyang District, Beijing 100029, China. ${ }^{2}$ Innovation Academy for Earth Science, Chinese Academy of Sciences, Beijing 100029, China. ${ }^{3}$ College of Earth and Planetary Sciences, University of Chinese Academy of Sciences, Beijing 100049, China. ${ }^{4}$ Institute of Applied Physics and Computational Mathematics, Beijing 100094, China.

Published online: 25 February 2021 the source, provide a link to the Creative Commons licence, and indicate if changes were made. The images or other third party material in this article are included in the article's Creative Commons licence, unless indicated otherwise in a credit line to the material. If material is not included in the article's Creative Commons licence and your intended use is not permitted by statutory regulation or exceeds the permitted use, you will need to obtain permission directly from the copyright holder. To view a copy of this licence, visit http://creativeco mmons.org/licenses/by/4.0/. 
Claesson J, Hellström G. Multipole method to calculate borehole thermal resistances in a borehole heat exchanger. HVAC\&R Res. 2011;17(6):895-911.

De Carli MD, Tonon M, Zarrella A, Zecchin R. A computational capacity resistance model (CaRM) for vertical groundcoupled heat exchangers. Renew Energy. 2010;35(7):1537-50.

Diersch HJG. FEFLOW: finite element modeling of flow, mass and heat transport in porous and fractured media. Berlin: Springer; 2014.

Erol S, Bertrand F. Multilayer analytical model for vertical ground heat exchanger with groundwater flow. Geothermics. 2018;71:294-305.

Eskilson P. Thermal analysis of heat extraction boreholes. Doctoral Thesis, Department of Mathematical Physics, University of Lund, Sweden; 1987.

Hellström G. Ground heat storage thermal analysis of duct storage systems. Doctoral Thesis, Department of Mathematical Physics, University of Lund, Sweden; 1991.

Hellström G, Sanner B. Earth energy designer: software for dimensioning of deep boreholes for heat extraction. Lund: Lund University; 1994. p. 185-92.

Holmberg H, Acuña J, Næss E, Sønju OK. Deep borehole heat exchangers, application to ground source heat pump systems. In: Proceed World Geothermal Congress. 2015.

Kim EJ, Bernier M, Cauret O, Roux JJ. A hybrid reduced model for borehole heat exchangers over different time-scales and regions. Energy. 2014;77:318-26.

Kolditz O, Bauer S, Bilke L, Böttcher N, Delfs JO, Fischer T, et al. OpenGeoSys: an open-source initiative for numerical simulation of thermo-hydro-mechanical/chemical (THM/C) processes in porous media. Environ Earth Sci. 2012;67(2):589-99.

Le Lous M, Larroque F, Dupuy A, Moignard A. Thermal performance of a deep borehole heat exchanger: insights from a synthetic coupled heat and flow model. Geothermics. 2015;57:157-72.

Li M, Lai ACK. Heat-source solution to heat conduction in anisotropic media with application to pile and borehole ground heat exchangers. Appl Energy. 2012;96:451-8.

Li M, Lai ACK. Analytical model for short-time responses of ground heat exchangers with U-shaped tubes: model development and validation. Appl Energy. 2013;104:510-6.

Li M, Lai ACK. Review of analytical models for heat transfer by vertical ground heat exchangers (GHEs): a perspective of time and space scales. Appl Energy. 2015;151:178-91.

Li M, Li P, Chan V, Lai ACK. Full-scale temperature response function (G-function) for heat transfer by borehole ground heat exchangers (GHEs) from sub-hour to decades. Appl Energy. 2014;136:197-205.

Li XX, Hu XM, Zhang ZW. Calculation method of thermal response radius for vertical borehole heat exchangers. Transact Chin SocAgricEng. 2015;31(17):248-53.

Liu J. Discussion on several basic problems of underground heat transfer process of ground source heat pump system. Doctoral Thesis, Tongji University, China; 2010.

Mingzhi Y, Tenteng M, Kai Z, Ping C, Aijuan H, Zhaohong F. Simplified heat transfer analysis method for large-scale boreholes ground heat exchangers. Energy Build. 2016;116:593-601.

Molina GN, Blum P, Zhu K, Bayer P, Fang Z. A moving finite line source model to simulate borehole heat exchangers with groundwater advection. Int J ThermSci. 2011;50(12):2506-13.

Rees SJ, He M. A three-dimensional numerical model of borehole heat exchanger heat transfer and fluid flow. Geothermics. 2013:46:1-13.

Rivera JA, Blum P, Bayer P. Ground energy balance for borehole heat exchangers: vertical fluxes, groundwater and storage. Renew Energy. 2015;83:1341-51.

Saadi MS, Gomri R. Investigation of dynamic heat transfer process through coaxial heat exchangers in the ground. Int J Hydrog Energy. 2017;42(28):1-17.

Sapinska-Sliwa A, Rosen MA, Gonet A, Sliwa T. Deep borehole heat exchangers-a conceptual and comparative review. Int J Air Cond Refrig. 2016;24(1):1630001-15.

Schulte DO. Simulation and optimization of medium deep borehole thermal energy storage systems. Doctoral Thesis, Technische Universitat, Darmstadt; 2016.

Schulte DO, Rühaak W, Oladyshkin S, Welsch B, Sass I. Optimization of medium-deep borehole thermal energy storage systems. Energy Technol. 2016;4(1):104-13.

Seama KF, Rosen MA. Review of the modeling of thermally interacting multiple boreholes. Sustainability. 2013;5(6):2519-36.

Welsch B, Rühaak W, Schulte DO, Bär K, Sass I. Characteristics of medium deep borehole thermal energy storage. Int J Energy Res. 2016:40:1855-68.

Welsch B, Schulte DO, RühaakW, Bär K, Sass I. Thermal impact of medium deep borehole thermal energy storage on the shallow subsurface. In: EGU General Assembly Conference Abstracts. 2017.

Zarrella A, Emmi G, De Carli M. A simulation-based analysis of variable flow pumping in ground source heat pump systems with different types of borehole heat exchangers: a case study. Energy Convers Manag. 2017;131:135-50.

\section{Publisher's Note}

Springer Nature remains neutral with regard to jurisdictional claims in published maps and institutional affiliations. 